\title{
Pertukaran Peran Domestik dan Publik Menurut Perspektif Wacana Sosial Halliday
}

\author{
${ }^{1}$ Umaimah Wahid, ${ }^{2}$ Ferrari Lancia \\ Universitas Budi Luhur, Jl. Ciledug Raya No.99, Jakarta Selatan \\ Email: ${ }^{1}$ umaimah.wahid@budiluhur.ac.id, ${ }^{2}$ flancia80@gmail.com
}

\begin{abstract}
Abstrak: Penelitian mengenai teks sinetron televisi 'Dunia Terbalik”' memfokuskan pada konstruksi peran perempuan dan laki-laki. Selama ini, laki-laki berperan sebagai kepala keluarga, pemimpin dan pencari nafkah sebagai representasi wilayah publik, sementara perempuan lebih digambarkan berperan sebagai ibu rumah tangga, tidak berkerja, dan aktif di wilayah domestik. Penelitian ini bertujuan mengungkap, mengkritisi, dan melakukan interpretasi atas realitas yang tidak biasa tersebut sebagai sebuah fenomena yang menarik walau tampaknya pertukaran peran tersebut banyak terjadi ditengah masyarakat. Dengan menggunakan teori dan metode wacana M.K. Halliday serta dilengkapi dengan pemahaman peran domestik dan publik yang merupakan hasil konstruksi sosial yang tidak mungkiun dinafikan lagi. Perempuan mempunyai kemana pun dan kesanggupan untuk berperan sebagai pencari nafkah menggantikan peran yang selama ini dominasi laki-laki. Sednagkan laki-laki atau suami dalam sinetron tersebut cenderung 'menerima' perubahan peran mereka dikarenakan ketidakmampuan secara finansial, bahkan mereka'menikmati peran tersebut yang tampak tidak adil bagi perempuan. Laki-laki atau suami tetap menuntut perempuan atau istri untuk melakukan peran domestik jika mereka di rumah.
\end{abstract}

Kata kunci: peran domestik-publik, wacana sosial-Halliday

\begin{abstract}
The research on the text of television soap opera "Dunia Terbalik" focuses on the construction of the role of women and men. During this time, men are act as heads of families, leaders and breadwinners as regional representation, while women are more described as housewives, unemployed, and active in domestic areas. This study aims to uncover, criticize, and interpret the unusual reality as an interesting phenomenon that often occurs in the society. By using the theory and method of discourse M.K. Halliday and also equipped with an understanding of the role of domestic and public which is the result of social construction that may not be denied. Women have the ability to act as a breadwinner who replace the role that has been dominated by men. while men or husband in the soap opera 'accept', because their incapacity financially, they even enjoy the role that seems unfair to women. Men or husbands keep demanding women or wives to perform domestic roles if they are at home.
\end{abstract}

Keywords: domestic-public role, social discourse-Halliday 


\section{PENDAHULUAN}

Fenomena perempuan yang menjalankan peran publik dan pria yang menjalankan peran domestik dalam rumah tangga semakin banyak dijumpai saat ini. Fenomena wanita sebagai pencari nafkah utama dan sebaliknya, istilah pria sebagai bapak rumah tangga memang belum akrab di tengah kehidupan keluarga-keluarga dalam masyarakat Indonesia, meskipun pada kenyataannya terdapat beberapa daerah yang sudah terbiasa dengan istilah tersebut, bahkan hingga membudaya.

Tradisi yang kuat melekat dalam masyarakat kita ini kian dipertegas dalam ketentuan pada Undang-Undang Perkawinan Nomor 1 Tahun 1974, Pasal 31 , Ayat 3 yang menyatakan bahwa suami adalah kepala keluarga dan istri adalah ibu rumah tangga. Perkataan "ibu rumah tangga" tidak boleh dipandang sebagai penurunan kedudukan dan tidak boleh pula diartikan istri yang mempunyai kemauan dan kemampuan untuk bekerja di luar rumah tangganya dilarang melakukan pekerjaan tersebut.

Tema menarik untuk diangkat dan dianalisis mengingat bahwa apabila fenomena ini ditelaah dalam konteks gender, struktur sosial pada masyarakat Indonesia masih menganut konsep patriarki yang mana terdapat penegasan yang jelas mengenai peranan antara pria dan wanita dalam rumah tangga, dan pertukaran peran antara pria dan wanita dalam rumah tangga tersebut tentunya akan memberikan perspektif lain bagi pembaca dalam memandang, menilai, dan memahami fenomena ini. Gender didefinisikan sebagai sifat yang melekat pada kaum lelaki dan perempuan yang dikonstruksi berdasarkan sosial dan kultural, yaitu maskulin atau feminin (Esplen dan Jolly, 2006).

Adanya perbedaan gender melahirkan peran-peran gender yang melekat pada laki-laki dan perempuan. Dari peran gender tersebut, dapat dilihat relasi gender yang didefinisikan sebagai pola hubungan antara lakilaki dan perempuan yang dikonstuksi secara sosial (Wiyatmi, 2008). Karena merupakan konstruksi sosial, dalam relasi gender kelompok gender tertentu dianggap memiliki kedudukan yang lebih tinggi (mendominasi) dan ada yang didominasi, namun ada pula yang setara. Tetapi dalam masyarakat patriarki, lakilaki dianggap memiliki kedudukan yang dominan, sementara perempuan berada dalam subordinat.

Fenomena pertukaran peran antara pria dan wanita dalam rumah tangga ini direfleksikan dalam sinetron Dunia Terbalik yang tayangan perdananya dimulai pada 5 Januari 2017. Sinetron yang diproduksi MNC Pictures dan ditayangkan di RCTI ini menggambarkan dan mengangkat realita yang terjadi di Desa Ciraos, Jawa Barat, yang mana pihak perempuannya dikirim menjadi Tenaga Kerja Wanita (TKW) di luar negeri dan harus mencari nafkah menggantikan peran seorang suami dalam mencari uang. Sementara, para suami harus mendidik anak serta mengurus rumah tangga yang biasanya menjadi urusan para istri.

Istri yang berperan sebagai pencari nafkah utama dalam keluarga dipicu oleh berbagai macam latar belakang di antaranya seperti akan mendapatkan penghasilan yang lebih besar mengingat relatif rendahnya penghasilan suami yang mayoritas berprofesi sebagai buruh tani.

Salah satu faktor tersebut yang mendorong para wanita/ istri di desa itu untuk bekerja sebagai TKW di luar negeri. Berdasarkan latar belakang di atas, permasalahan penelitian dapat dirumuskan sebagai berikut: Bagaimana dan mengapa wacana mengenai isu-isu tentang peran pria dan wanita, baik dalam ranah domestik maupun publik, yang direpresentasikan dalam sinetron "Dunia Terbalik"?

Teori yang digunakan dalam 
penelitian ini adalah teori nature dan nurture. Teori ini mengemukakan perihal asal-usul lahirnya sifat feminin dan maskulin pada manusia. Teori nature menyebutkan bahwa sifat maskulin dan feminin ada hubungannya dengan, bahkan tidak lepas dari, pengaruh perbedaan biologis (seks) pria dan wanita. Perbedaan biologis pria dan wanita adalah alami, begitu pula sifat maskulin dan feminin yang dibentuknya. Metode yang akan digunakan untuk menganalisis pesanpesan dalam sinetron "Dunia Terbalik" ini adalah Analisis Wacana dengan Perspektif M.A.K Halliday yang biasa disebut Trilogi Konteks Situasi. Halliday melalui teori analisis wacananya menyatakan bahwa bahasa memiliki 3 (tiga) fungsi utama, yakni mengomunikasikan proses terjadinya peristiwa di dunia dan semua yang terlibat di dalamnya (fungsi ideasional), mengekspresikan sikap penutur terhadap proposisi yang sudah disusun, dan mengekspresikan relasi antara penutur dan mitra tutur (fungsi interpersonal) dan menyajikan ekspresi tersebut secara koherensif dan memadai melalui teks (fungsi tekstual).

\section{Teori Wacana dan Analisis Wacana Halliday}

Wacana dalam arti suatu ujaran sangat tergantung pada konteks sosial yang ada, termasuk status sosial, hak dan kewajiban peserta interaksi, serta latar belakang pengalaman yang mereka alami bersama (Kartomihardjo, 1988). Wacana adalah penggunaan bahasa untuk menggambarkan realitas Unsur konteks dan situasi merupakan ciri mendasar dalam sebuah wacana. Hal ini, antara lain, sesuai dengan apa yang dikemukakan Ibrahim (1993).

Berkaitan dengan keberadaan wacana, maka perlu dikemukakan tentang persyaratan terbentuknya sebuah wacana. (Hamad, 2007) Persyaratan terbentuknya sebuah wacana, yaitu adanya topik, adanya tuturan pengungkap topik beserta jabaran-jabaran topik, dan adanya kohesi dan koherensi (Oka dan Suparno, 1994). Pertama, topikadalah halyang dibicarakan dalam wacana. Kedua, tuturan yang berupa kalimat atau untaian kalimat yang membentuk teks, baik tertulis maupun lisan. Ketiga, yang berupa kohesi dan koherensi. Kohesi merupakan hubungan formal (tampak pada bentuk), sedangkan koherensi merupakan hubungan semantik antarkalimat atau antarbagian wacana, yakni hubungan yang serasi antara proposisi satu dan yang lain, atau antara makna satu dan makna yang lain.

Analisis wacana adalah analisis atas bahasa yang digunakan (Brown dan Yule, 1983). Tujuan analisis wacana adalah untuk memeriksa wacana (sebagai salah satu eksponen bahasa) dalam fungsinya sebagai alat komunikasi (Baryadi, 2001). Analisis wacana meletakkan titik berat pada fungsi bahasa sebagai alat interaksi antara penulis dan pembaca atau antara pembicara dan pendengar (Wahab, 1998). Analisis wacana juga dipandang sebagai studi tentang struktur pesan dalam komunikasi (Sobur, 2002). Jadi, fungsi bahasa sebagai alat komunikasi semakin tampak terwadahi dengan adanya analisis wacana. Penyebutan komunikasi di sini tentu berorientasi pada keberadaan bahasanya, bukan komunikasi dalam arti umum. Penggunaan bahasa dalam komunikasi pasti disertai dengan konteks. Karena itu, salah satu titik perhatian analisis wacana adalah teks dan konteks (Sobur, 2002).

Pendekatan analisis wacana milik M.A.K. Halliday digunakan terutama untuk menganalisis fungsi pragmatis elemen linguistic. Penelitian ini menggunakan salah satu analisis wacana milik M. A. K. Halliday yang biasa disebut Trilogi Konteks Situasi. Trilogi Konteks Situasi ini mencakup pengkajian dari aspek pelibat, medan wacana, dan modus wacana. Halliday memiliki nama 
lengkap Michael Alexander Kirkwood Halliday, berkebangsaan Inggris, lahir di Inggris pada 13 April 1925, namun saat ini tinggal di Australia. Menurutnya, bahasa itu tidak berisi kalimat-kalimat, tetapi bahasa itu berisi teks atau wacana, yakni pertukaran makna (exchange of meaning) dalam konteks interpersonal. Wacana Sosial, Ibnu Hamad (2007) menyebutkan dengan semiotika sosial memandang bahwa sebuah naskah terdiri dari tiga komponen utama: medan wacana, pelibat wacana, dan sarana wacana.

Situasi adalah lingkungan tempat teks. Konteks situasi adalah keseluruhan lingkungan, baik lingkungan tutur (verbal), maupun lingkungan tempat teks itu diproduksi (diucapkan atau ditulis). Dalam pandangan Halliday (1978), konteks situasi terdiri atas tiga unsur, yaitu: (1) Medan Wacana (field of discourse) yaitu konteks situasi yang merujuk kepada aktivitas sosial yang sedang terjadi serta latar institusi tempat satuan-satuan bahasa itu muncul. Dalam menganalisis medan wacana terdapat tiga hal yang perlu ditelaah, yaitu ranah pengalaman, tujuan jangka pendek, dan tujuan jangka panjang. Ranah pengalaman merujuk pada ketransitifan yang mempertanyakan apa yang terjadi dengan seluruh "proses", "partisipan", dan "keadaan". (2) Pelibat Wacana (tenor of discourse, yaitu pelibat wacana adalah konteks situasi yang merujuk pada narasumber yang dikutip, termasuk pemahaman peran dan statusnya dalam konteks sosial dan lingual. Untuk menganalisis pelibat wacana, ada tiga hal yang perlu ditelaah, yaitu peran agen atau masyarakat, status sosial, dan jarak sosial. Peran status dan jarak sosial dapat bersifat sementara ataupun bisa juga permanen. (3) Modus Wacana (mode of discourse) adalah konteks situasi yang merujuk pada bagian bahasa yang sedang dimainkan dalam situasi, termasuk saluran yang dipilih, apakah lisan atau tulisan.

Untuk menganalisisnya maka terdapat lima hal yang perlu ditelaah yaitu peran bahasa, tipe interaksi, medium, saluran, dan modus retoris. Peran bahasa terkait dengan kedudukan bahasa dalam aktivitas bisa bersifat wajib maupun pendukung. Peran wajib terjadi apabila bahasa sebagai aktivitas keseluruhan. Peran tambahan terjadi apabila bahasa membantu aktivitas lainnya.

Halliday mengemukakan bahwa teks itu selalu dilingkupi konteks situasi dan konteks budaya (Butt et al., 1999). Mengkaji bahasa secara fungsional pada hakikatnya mengkaji tiga aspek yang saling terkait, yakni teks, konteks situasi (context of situation), dan konteks budaya (context of culture). Dalam teks, selalu terkandung unsur tekstur dan struktur. Oleh Butt et al. (1999), kajian Halliday terlihat pada GAMBAR 1.

\section{Perdebatan Gender : Peran Domestik dan Publik}

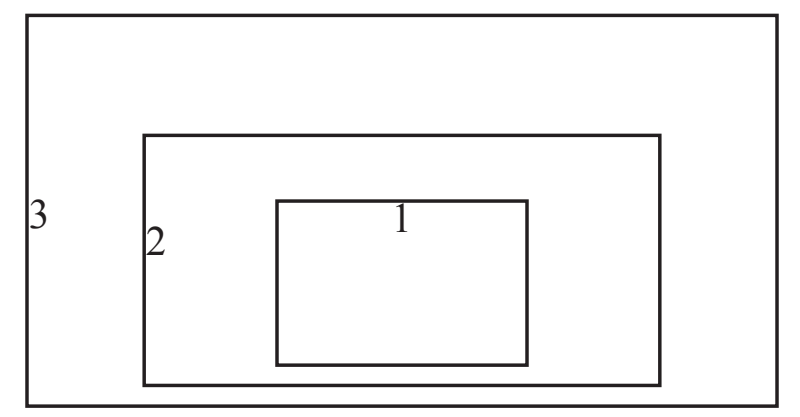

GAMBAR 1. Model Linguistik Fungsional-Sistemik Halliday Keterangan: 1. Teks, 2. Konteks Situasi, 3. Konteks Budaya 
Isu-isu gender di ranah domestik dan publik membahas masalah yang muncul karena adanya ideologi gender. Isu tersebut berupa ketimpangan atau bias gender yang mengakibatkan diskriminasi dan eksploitasi terhadap salah satu pihak, yaitu perempuan dirugikan sedangkan laki-laki diuntungkan. Ketimpangan gender yang menjadi isu gender tersebut berupa proses dan produk kategorisasi yang mencakup: (a) Sifat: maskulinfeminin; (b) Lingkup kegiatan: publikdomestik; (c) Fungsi: produktifreproduktif; (d) Peran: kepala keluargaibu rumah tangga.

Isu gender di ranah domestik dan publik tersebut mencakup: (a) Gender Stereotype (pelabelan negatif gender): perkasa-lemah-lembut; (b) Gender Norm: kepala keluarga-ibu rumah tangga; (c) Gender Role: pencari nafkah-pengelola rumah tangga; (d) Subordinasi: pemimpin-pihak yang dipimpin; (e) Marginalisasi: kalau terpaksa baru dimarginalkan-diutamakan untuk dimarginalkan; (f) Burden (beban): mono burden-multi burden; (g) Violence (kekerasan): sebagian besar menjadi pelaku-sebagian besar menjadi korban kekerasan (Wibowo, 2011)

Ranah domestik akrab dengan segala sesuatu yang berkaitan dengan kegiatan di dalam rumah tangga. Sosok yang dekat dengan ranah ini adalah perempuan. Hadirnya perempuan di ranah domestik ini seolah sudah menjadi kodrat alamiahnya. Hal ini dipicu karena proses untuk menjadi seorang perempuan yang berada dalam lingkungan domestik berkaitan dengan sifat alami perempuan yang berkaitan dengan teori nature, yaitu sifat dasar manusia yang terbentuk karena faktor biologis. Perempuan yang telah menikah dan punya anak menjadi begitu lekat dengan ranah ini.

Kegiatan yang berlangsung dalam ranah domestik ini bisa berupa apapun, asal terjadi di dalam lingkungan rumah, misalnya; berbagai pekerjaan rumah tangga, mulai dari membersihkan rumah hingga mengurus keperluan keluarga. Sedangkan ranah publik adalah kebalikan dari ranah domestik. Jika ranah domestik dikaitkan dengan sifat feminin pada perempuan, maka ranah domestik justru dikaitkan dengan sifat maskulin pada laki-laki. Dari sini diambil sedikit gambaran mengenai ranah publik ini. Laki-laki pada umumnya mendominasi pekerjaan-pekerjaan yang di ranah publik. Pekerjan itu sangat beragam, bisa apa saja, asal ruang lingkupnya berada di luar lingkungan rumah.

Peran domestik yang maksudnya adalah ruang lingkup kegiatan perempuan yang berhubungan dengan kegiatan di rumah dan kodratnya sebagai seorang perempuan, misalnya menjadi ibu yang bertanggung jawab dalam hal pengasuhan anak dan urusan rumah tangga lainnya, seperti membersihkan rumah, juga memasak.

Wacana gender yang sudah cukup lama terdengar telah membuat peran lakilaki dan perempuan dalam tatanan sosial menjadi sedikit berbeda. Sedangkan dari pihak laki-laki tetap identik dengan pekerjaan pokoknya, yaitu di ranah publik, bekerja di luar rumah. Berubahnya peranperan wanita ini, seharusnya membawa konsekuensi berubah pula peran-peran pria, sekaligus tatanan sosial yang ada (Nauly, 2002). Perempuan yang notabene dikatakan lebih lemah daripada kaum laki-laki nyatanya sudah bisa membagi dirinya antara bekerja di luar rumah dan mengurus rumah tangga (anak dan suami).

Seharusnya, jika dilihat dari sisi keadilan, seorang laki-laki atau suami dalam hal ini juga harus bisa membagi waktunya untuk mengurus rumah tangga. Beberapa laki-laki yang telah menyadari tentang peran gender biasanya dikalahkan dengan rasa khawatir atau malu jika dia melakukan pekerjaan yang 
identik dengan perempuan. Memang sangat susah untuk mengubah pandangan masyarakat yang telah berkembang sekian lama dan bahkan didukung oleh adat budaya, norma, serta dalil-dalil agama.

\section{METODE}

Metode penelitian yang digunakan adalah analisis wacana dengan sumber data utama berupa scene-scene yang diperoleh dari menonton dan mengamati sinetron "Dunia Terbalik". Analisis terhadap sinetron "Dunia Terbalik" yang menjadi obyek penelitian ini dilakukan dengan mengartikan wacanawacana yang muncul dalam sinema dan menggambarkan peran perempuan juga pria dalam ranah domestik dan publik.

Proses pemaknaan wacana dalam penelitian ini dilakukan dengan cara melihat scene apa saja yang dirasa sesuai dengan rumusan masalah, kemudian dengan metode analisis wacana Halliday dilihat isu-isu penting apa saja yang paling sering muncul dalam film, lalu melihat siapa saja pelibat dalam scene tersebut, bagaimana medan wacana di dalam scene yang dipilih dan apa modusnya. Scene yang akan dipilih sebelumnya dikelompokkan terlebih dahulu menjadi beberapa bagian, meliputi wacana tentang peran pria dan wanita dalam ranah domestik, yaitu kehidupan pribadi pelaku utama; kemudian wacana peran pria dan wanita dalam ranah publik yang berkaitan dengan pelaku utama dan pekerjaannya.

Dalam sinetron "Dunia Terbalik", disajikan realita yang menggambarkan pertukaran peran antara pria dan wanita dalam rumah tangga. Apabila kita merujuk kembali kepada konsep ataupun paradigma yang telah terbentuk melalui konstruksi sosial budaya di Indonesia, tentunya ekspekstasi dari masyarakat akan kembali kepada nilai-nilai maupun norma-norma yang telah lama terbentuk yaitu laki-laki memegang peranan dalam ranah publik. Namun, pada sinetron "Dunia Terbalik", fenomena digambarkan secara terbalik dan merupakah hal yang sudah biasa, bahkan sudah menjadi tradisi karena hal tersebut bersifat kasuistik ketika pria terkondisikan untuk menjalankan peran dalam ranah domestik karena sebagian besar wanita di desa tersebut menjadi Tenaga Kerja Wanita (TKW)

Pada bagian ini akan ditampilkan potongan-potongan adegan yang menunjukkan peran para pria di desa tersebut dalam ranah domestik yang direpresentasikan dalam obyek penelitian, sesuai dengan pengelompokkan yang telah dibuat dan batasan-batasan yang telah ditentukan, yaitu yang berhubungan dengan peran pria dalam ranah domestik, bagaimana sifat dari pelaku utama, baik sifat alamiahnya sebagai pria maupun sifat yang terbentuk karena lingkungan tempat tinggalnya. Kondisi tersebut mengakibatkan istri tidak dapat mengurus anaknya, sebaliknya digantikan oleh para suami.

\section{HASIL DAN PEMBAHASAN}

Analisis terhadap sinetron "Dunia Terbalik" yang menjadi obyek penelitian ini dilakukan dengan mengartikan wacana-wacana yang muncul dalam sinetron dan menggambarkan peran perempuan dan laki-laki dalam ranah domestik dan publik. Proses pemaknaan wacana dalam penelitian ini dilakukan dengan cara melihat scene apa saja yang dirasa sesuai dengan rumusan masalah, kemudian dengan metode analisis wacana Halliday dilihat isu-isu penting apa saja yang paling sering muncul dalam film, lalu melihat siapa saja pelibat dalam scene tersebut, bagaimana medan wacana di dalam scene yang dipilih dan apa modusnya. Peneliti menggunakan analisis wacana dari M. A. K. Halliday yang mengemukakan tentang makna dalam 
suatu bahasa ataupun teks, di antaranya yaitu Medan Wacana (field of discourse), Pelibat Wacana (tenor of discourse), dan Sarana atau Modus Wacana (mode of discourse). Tiga unsur inilah yang peneliti kaji dalam mengamati scene-scene apa saja yang paling sesuai rumusan masalah, kemudian dilihat isu-isu penting apa saja yang paling sering muncul dalam sinetron, lalu melihat siapa saja pelibat dalam scene tersebut, bagaimana medan wacana di dalam scene yang dipilih dan apa modusnya.

Pada bagian ini akan ditampilkan potongan-potongan adegan yang menunjukkan peran para pria di desa tersebut dalam ranah domestik yang direpresentasikan dalam obyek penelitian, sesuai dengan pengelompokan yang telah dibuat dan batasan-batasan yang telah ditentukan, yaitu yang berhubungan dengan peran pria dalam ranah domestik, bagaimana sifat dari pelaku utama, baik sifat alamiahnya sebagai pria maupun sifat yang terbentuk karena lingkungan tempat tinggalnya. Kondisi tersebut mengakibatkan istri tidak dapat mengurus anaknya, sebaliknya digantikan oleh para suami.

Wacana peran laki-laki dalam ranah domestik ditampilkan dan dianalisis melalui scene-scene atau adegan-adegan sebagai berikut:

GAMBAR 2 memperlihatkan medan wacana bahwa Dokter Clara merasa heran melihat para laki-laki

TABEL 1. Kerangka Analisis Data 1

Wacana Peran Laki-laki dalam Ranah Domestik, Adegan Episode 13 Februari 2017

\begin{tabular}{|c|c|c|c|}
\hline $\begin{array}{c}\text { Tanggal } \\
\text { Scene/ Adegan }\end{array}$ & $\begin{array}{c}\text { Temuan } \\
\text { Medan Wacana } \\
\text { (Field of Discourse) }\end{array}$ & $\begin{array}{c}\text { Temuan } \\
\text { Pelibat Wacana } \\
\text { (Tenor of } \\
\text { Discourse) }\end{array}$ & $\begin{array}{c}\text { Temuan } \\
\text { Sarana Wacana (Mode } \\
\text { of Discourse) }\end{array}$ \\
\hline 13 Februari 2017 & $\begin{array}{l}\text { Dalam scene yang } \\
\text { berlangsung di Desa } \\
\text { Ciraos tersebut terlihat } \\
\text { bahwa Dokter Clara } \\
\text { merasa heran melihat } \\
\text { para laki-laki sebagai } \\
\text { kepala keluarga, namun } \\
\text { berbelanja sayur di } \\
\text { penjual sayur keliling } \\
\text { bersama-sama kepala } \\
\text { keluarga lainnya. } \\
\text { Meskipun menyimpan } \\
\text { kebingungan melihat } \\
\text { hal itu, namun Dokter } \\
\text { Clara mengatakan bahwa } \\
\text { bapak-bapak tersebut } \\
\text { rajin karena pagi-pagi } \\
\text { sudah berbelanja sayur, } \\
\text { yang mana seharusnya } \\
\text { hal itu dilakukan oleh } \\
\text { perempuan atau istri. }\end{array}$ & $\begin{array}{l}\text { Dokter Clara } \\
\text { (diperankan oleh } \\
\text { Syahnaz Sadiqah) } \\
\text { yaitu seorang dokter } \\
\text { Puskesmas yang } \\
\text { datang dari Jakarta; } \\
\text { Akum (diperankan } \\
\text { Agus Kuncoro) yaitu } \\
\text { seorang bapak dengan } \\
\text { sifat lemah lembut } \\
\text { yang berusahan } \\
\text { membesarkan anaknya } \\
\text { yang masih SMP, } \\
\text { sementara istrinya } \\
\text { bekerja sebagai TKW; } \\
\text { Idoy (diperankan } \\
\text { oleh Bembeng) yaitu } \\
\text { seorang suami yang } \\
\text { polos dengan istri } \\
\text { yang bekerja sebagai } \\
\text { TKW; dan Dadang } \\
\text { (diperankan oleh Indra } \\
\text { Birowo) yaitu seorang } \\
\text { suami yang memiliki } \\
\text { istri TKW yang } \\
\text { berpenghasilan paling } \\
\text { besar dan memiliki } \\
\text { sifat sombong. }\end{array}$ & $\begin{array}{l}\text { Gaya bahasa yang terdapat } \\
\text { dalam scene ini adalah } \\
\text { majas apofasisi/ preterisio, } \\
\text { yaitu gaya bahasa yang } \\
\text { digunakan mengandung } \\
\text { unsur kontradiksi seperti } \\
\text { terlihat memuji tetapi } \\
\text { sebenarnya mengejek, atau } \\
\text { misalnya terlihat menerima } \\
\text { namun sebenarnya menolak. } \\
\text { Percakapan dilakukan } \\
\text { dengan dialog secara lisan } \\
\text { anatara para pelibat wacana } \\
\text { dan bahasa digunakan secara } \\
\text { keseluruhan dalam aktivitas } \\
\text { percakapan. }\end{array}$ \\
\hline
\end{tabular}




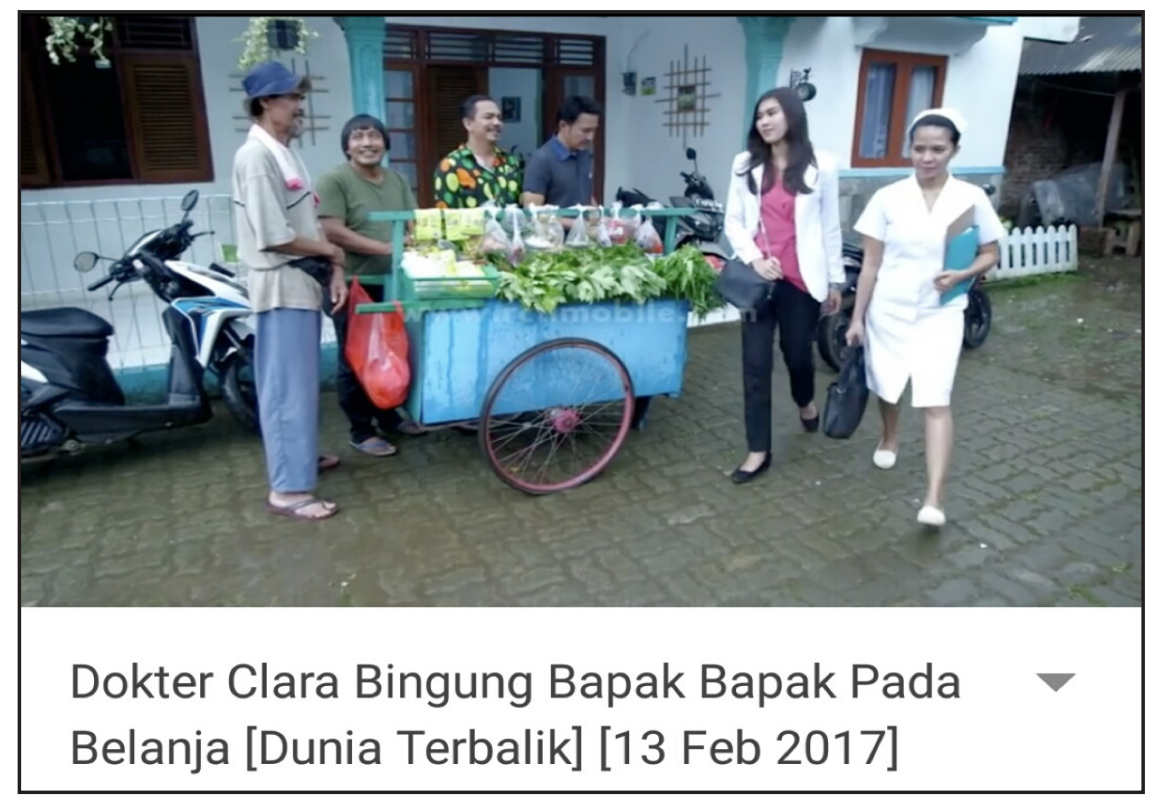

GAMBAR 2. Scene sinetron "Dunia Terbalik" 13

Februari 2017

sebagai kepala keluarga namun berbelanja sayur di penjual sayur keliling bersamasama kepala keluarga lainnya. Meskipun menyimpan kebingungan melihat hal itu, namun Dokter Clara mengatakan bahwa bapak-bapak tersebut rajin karena pagi-pagi sudah berbelanja sayur, yang mana seharusnya hal itu dilakukan oleh perempuan atau istri.

Percakapan pelibat wacana yaitu Dokter Clara (diperankan oleh Syahnaz Sadiqah), Akum (diperankan oleh Agus Kuncoro), Idoy (diperankan oleh Bembeng), dan Dadang (diperankan oleh Indra Birowo), memperlihatkan modus wacana dengan gaya bahasa yang terdapat dalam scene ini, yaitu Majas Apofasisi/ Preterisio, yaitu gaya bahasa yang digunakan mengandung kontradiksi seperti terlihat memuji tetapi sebenarnya mengejek, atau misalnya terlihat menerima namun sebenarnya menolak. Faktor budaya membuat Dokter Clara secara tidak langsung masih menganggap hal tersebut adalah hal yang tidak lumrah. Hal tersebut sesuai dengan kutipan wawancara dengan A. D. Eridani (Direktur LSM Rahima) yang menyatakan hal sebagai berikut:
Ketika perempuan meyeberang ke fungsi publik tidak dipermasalahkan, tapi ketika laki-laki menyeberang ke fungsi domestiknya kenapa kok jadi dipermasalahkan? Problemnya sebenarnya disitu. Ketika lakilaki menyeberang kesini, dia jadi dipermasalahkan. Masalahnya tidak hanya di Indonesia. Budaya patriarki kan mengunggulkan laki-laki.

Dari analisis dan pernyataan di atas, dapat disimpulkan bahwa faktor budaya, khususnya di Indonesia, yang melanggengkan budaya patriarki, berperan sangat besar dalam membentuk wacana yang menegaskan bahwa laki-laki sepantasnya berada di ranah publik dan perempuan di ranah domestik, meskipun Dokter Clara sebagai salah satu pelibat wacana juga berperan sebagai dokter yang mana pekerjaannya berada di ranah publik.

GAMBAR 3 memperlihatkan medan wacana ketika para laki-laki sebagai kepala rumah tangga yang sedang mengerjakan pekerjaan-pekerjaan rumah tangga, atau dengan kata lain sedang menjalankan fungsinya dalam wilayah domestik. Pelibat wacana dalam 


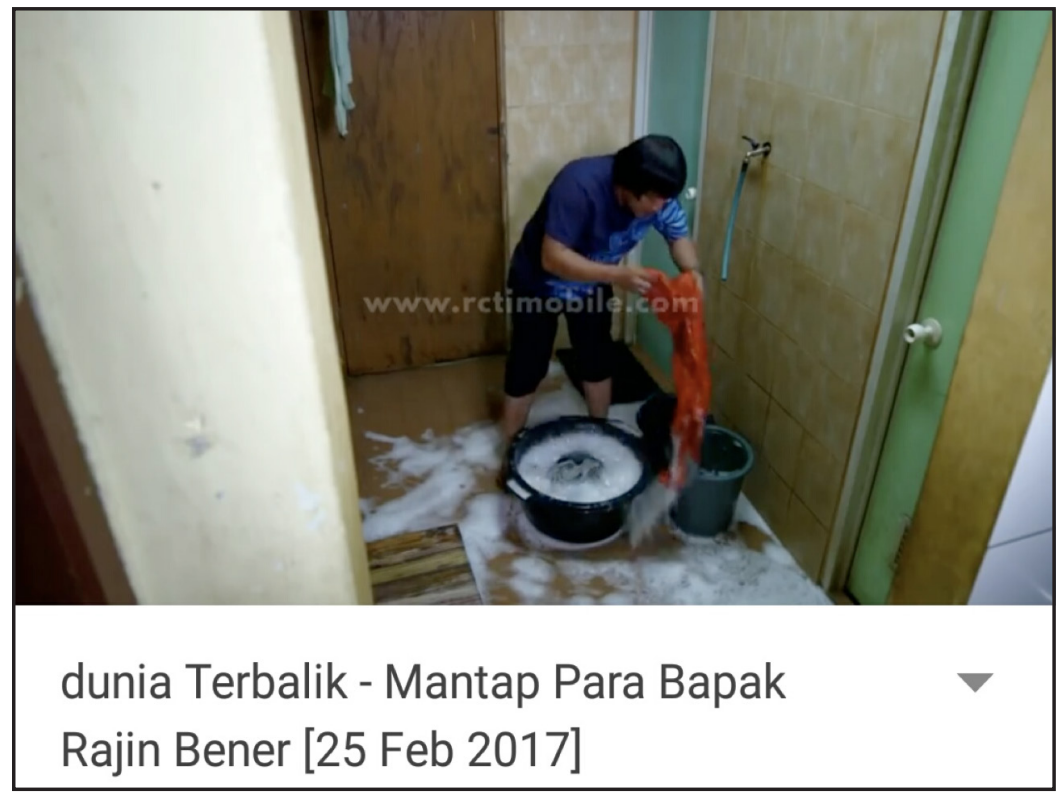

GAMBAR 3. Scene sinetron "Dunia Terbalik" 25 Februari 2017

scene-scenel adegan-adegan ini, yaitu Akum (diperankan oleh Agus Kuncoro), Idoy (diperankan oleh Bembeng), Dadang (diperankan oleh Indra Birowo), dan Aceng (diperankan oleh Sutan Simatupang), mereka memiliki persamaan yaitu memiliki istri yang bekerja di luar negeri sebagai TKW.

Sarana wacana memperlihatkan pesan disampaikan secara simbolik melalui scene-scene yang menunjukkan para pelibat wacana sedang melakukan aktivitas rumah tangga yang biasanya dikerjakan oleh perempuan atau istri, seperti memasak dan mencuci. Scene ini secara tidak langsung menampilkan wacana dan konsep laki-laki yang berada di dalam wilayah domestik dan dilanggengkan melalui sebuah pola budaya yang sedang berlangsung di desa tersebut, sehingga hal itu menjadi hal yang lumrah. Terkait dengan konteks ini, A. D. Eridani dalam wawancara menyampaikan pula hal sebagai berikut:

"Yang membedakan laki-laki dan perempuan sebenarnya kan jenis kelamin dan fungsi yang mengikutinya. Tapi, produksi, peran publik itu kan bisa dipertukarkan. Nah ini yang kemudian disebut dengan gender.
Menurut saya, sebaiknya tidak saklek bahwa peran laki-laki itu harus di ruang publik, dan perempuan hanya domestik. Kita lihat faktanya sekarang banyak sekali perempuan-perempuan yang bekerja di luar rumah. Ya contohnya dalam sinetron 'dunia terbalik. Rumah tangga itu bisa berjalan karena kontribusi dari kedua orang ini. Jadi kalau pendapat saya sih sebenarnya kuncinya itu adanya dialog, adanya komunikasi antara pihak-pihak ini.. Asal mereka berdua merasa itulah yang paling cocok untuk mereka berdua jadi tidak menekan salah satu fihak. Apabila dua-duanya pun ingin mengambil sector public ya tidak apa-apa asal atas kesepakatan. Tapi urusan domestic jangan kemudian hanya diserahkan juga kepada hanya salah satu fihak.

Dari analisis dan pernyataan di atas, dapat disimpulkan bahwa pola budaya yang sedang berlangsung dalam suatu daerah juga ikut menentukan pola pikir atau wacana masyarakat setempat terhadap konteks gender, dalam hal ini pandangan warga Desa Ciraos yang sudah terbiasa dengan adanya fenomena laki-laki atau suami yang menjalankan fungsinya 
dalam wilayah domestik dan perempuan atau istri pada posisi sebaliknya. Tuntutan ekonomi dan motivasi untuk memiliki penghasilan besar dengan cara menjadi TKW dan meninggalkan para suami untuk mengurus hal-hal rumah tangga sudah menjadi hal yang akhirnya dianggap lumrah. Hal tersebut dapat berjalan karena adanya pembicaraan dan kesepakatan mengenai pembagian peran dan fungsi antara laki-laki/suami dan perempuan/istri, sehingga masingmasing pihak bersifat saling melengkapi.

\section{Wacana Peran Perempuan dalam Ranah Publik}

Poin sebelumnya telah membahas bagaimana peran pelaku utama dalam ranah domestik. Telah dijelaskan sebelumnya yang dimaksud dengan ranah domestik adalah ruang lingkup kegiatan pelaku utama sesuai perannya sebagai ibu dan perempuan yang mana dalam hal ini digantikan oleh pria. Itu berarti hanya seputar kesibukannya di rumah bersama anak-anaknya. Poin kedua dalam penelitian ini mengenai perempuan, dalam penelitian ini yaitu pelaku utama dalam sinetron "Dunia Terbalik", dalam ranah publik. Ranah publik berarti segala jenis kegiatan yang dilakukan pelaku utama di luar rumah dalam upaya pencarian nafkah, yaitu lingkungan pekerjaannya dan segala macam hal yang berkaitan dengan kesibukannya sebagai Tenaga Kerja Wanita (TKW) di luar negeri.

Wacana peran perempuan dalam ranah publik ditampilkan dan dianalisis pula melalui scene-scene atau adeganadegan sebagai berikut:

Adegan pada GAMBAR 4 memperlihatkan percakapan antara Dadang dan istrinya melalui telepon. Tampak bahwa Dadang terkejut karena istrinya akan mengurangi kiriman uang kepada Dadang. Sebagai laki-laki, Dadang sudah merasa nyaman dengan kondisi istri yang mencari nafkah dengan penghasilan besar karena ia adalah pribadi yang gemar bermewahmewahan. Pelibat wacana dalam adegan ini hanya Dadang (diperankan oleh Indra Birowo) dan istrinya. Dadang menyampaikan secara hiperbolis kepada istrinya melalui percakapan via telepon bahwa apabila istrinya memangkas uang

TABEL 2. Kerangka Analisis Data

Wacana Peran Perempuan dalam Ranah Publik, Adegan Episode 1 Februari 2017

\begin{tabular}{|c|c|c|c|}
\hline $\begin{array}{c}\text { Tanggal Scene } \\
\text { Adegan }\end{array}$ & $\begin{array}{c}\text { Temuan } \\
\text { Medan Wacana (Field of } \\
\text { Discourse) }\end{array}$ & $\begin{array}{c}\text { Temuan } \\
\text { Pelibat Wacana } \\
\text { (Tenor of Discourse) }\end{array}$ & $\begin{array}{c}\text { Temuan } \\
\text { Sarana Wacana (Mode of } \\
\text { Discourse) }\end{array}$ \\
\hline 1 Februari 2017 & $\begin{array}{l}\text { Dalam adegan ini } \\
\text { diperlihatkan percakapan } \\
\text { antara Dadang dan istrinya, } \\
\text { Ikoh melalui telepon. } \\
\text { Diperlihatkan bahwa Dadang } \\
\text { terkejut karena istrinya akan } \\
\text { mengurangi kiriman uang } \\
\text { kepada Dadang. Sebagai laki- } \\
\text { laki, Dadang sudah merasa } \\
\text { nyaman dengan kondisi istri } \\
\text { yang mencari nafkah dengan } \\
\text { penghasilan besar karena ia } \\
\text { adalah pribadi yang gemar } \\
\text { bermewah-mewahan. Adegan } \\
\text { ini berlangsung di rumah } \\
\text { Dadang di Desa Ciraos. }\end{array}$ & $\begin{array}{l}\text { Dadang (diperankan } \\
\text { oleh Indra Birowo) } \\
\text { yaitu seorang laki- } \\
\text { laki/suami yang } \\
\text { sombong karena } \\
\text { memiliki istri TKW } \\
\text { yang berpenghasilan } \\
\text { paling besar di } \\
\text { Desa Ciraos; dan } \\
\text { istrinya, Ikoh } \\
\text { (diperankan oleh Tike } \\
\text { Priyatnakusumah) } \\
\text { sebagai istri yang } \\
\text { suka pamer harta. }\end{array}$ & $\begin{array}{l}\text { Dadang menyampaikan } \\
\text { secara hiperbolis kepada } \\
\text { istrinya melalui percakapan } \\
\text { via telepon bahwa apabila } \\
\text { istrinya memangkas } \\
\text { uang bulanan yang akan } \\
\text { dikirimkan, maka taraf } \\
\text { hidup keluarganya akan } \\
\text { menurun dan tidak bisa } \\
\text { bermewah-mewahan } \\
\text { lagi. Dalam percakapan } \\
\text { ini, bahasa dipergunakan } \\
\text { secara penuh. Interaksi } \\
\text { antara Dadang dan Ikoh } \\
\text { disampaikan dengan } \\
\text { visualisasi melalui dialog } \\
\text { secara lisan. }\end{array}$ \\
\hline
\end{tabular}




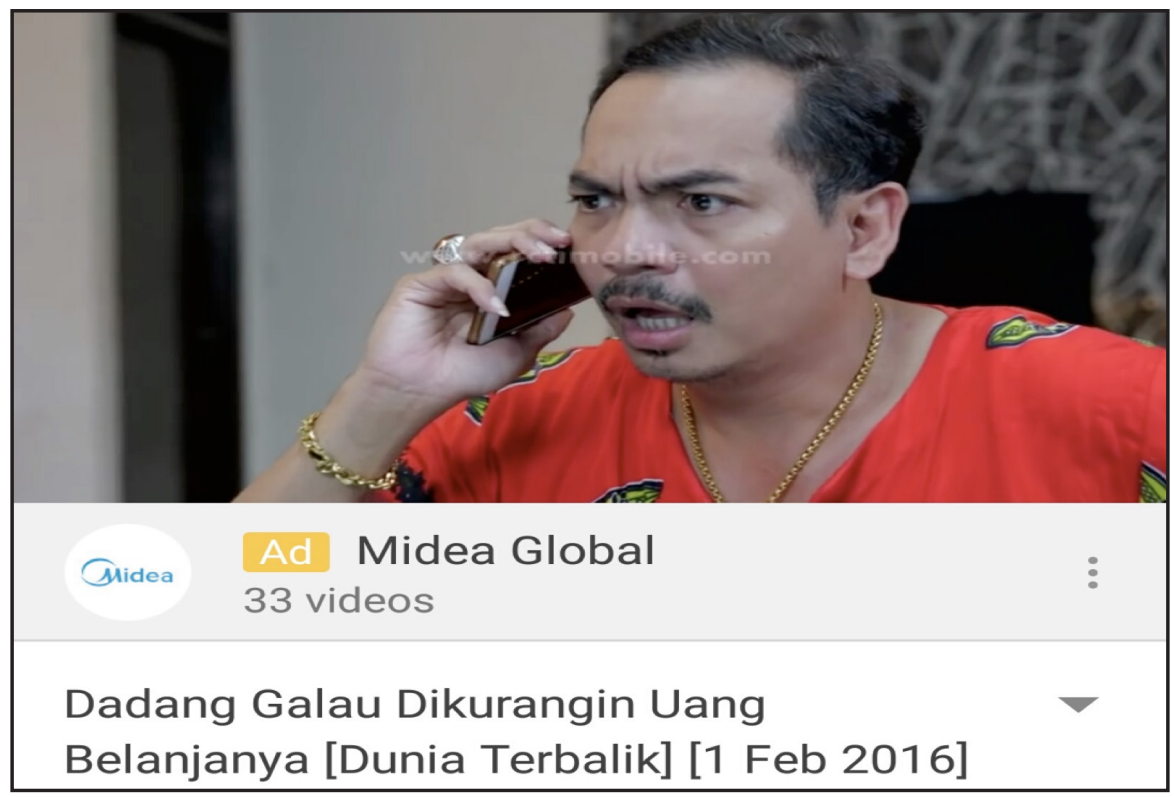

GAMBAR 4. Scene sinetron “Dunia Terbalik” 1 Februari 2017

bulanan yang akan dikirimkan, maka taraf hidup keluarganya akan menurun dan tidak bisa bermewah-mewahan lagi. Situasi ini menunjukkan fenomena suami yang sudah terlanjur mengandalkan istri dalam mencari nafkah, sementara ia tidak bersifat melengkapi (komplementer) untuk menjalankan fungsinya dalam rumah tangga. Wacana ini menegaskan sebuah konsep seorang laki-laki/suami yang tidak sepenuhnya menjalankan fungsinya yang berada dalam ranah domestik.

Adegan yang ditunjukkan pada
GAMBAR 5 memperlihatkan suami Yati memaksa agar ia segera bekerja kembali sebagai TKW. Menurut suami Yati, apabila dia tidak bekerja maka tidak ada yang mencari nafkah untuk keluarga. Yati tidak boleh melawan karena menurut suaminya, dialah kepala keluarga yang berhak memutuskan apapun. Percakapan yang sedang terlibat antara Yati dan suaminya memperlihatkan ungkapanungkapan suami dari Yati yang bertujuan untuk memaksa agar Yati kembali bekerja sebagai TKW untuk menafkahi rumahtangga.

TABEL 3. Kerangka Analisis Data

Wacana Peran Perempuan dalam Ranah Publik, Adegan Episode 11 Mei 2017

\begin{tabular}{|c|l|l|l|}
\hline $\begin{array}{c}\text { Tanggal } \\
\text { Scenel } \\
\text { Adegan }\end{array}$ & $\begin{array}{c}\text { Temuan } \\
\text { Medan Wacana (Field of } \\
\text { Discourse) }\end{array}$ & $\begin{array}{c}\text { Temuan } \\
\text { Pelibat Wacana } \\
\text { (Tenor of } \\
\text { Discourse) }\end{array}$ & $\begin{array}{c}\text { Temuan } \\
\text { Sarana Wacana (Mode of } \\
\text { Discourse) }\end{array}$ \\
\hline 11 Mei 2017 & $\begin{array}{l}\text { Adegan yang berlangsung di Desa } \\
\text { Ciraos ini memperlihatkan suami } \\
\text { Yati yang memaksa agar ia segera } \\
\text { bekerja kembali sebagai TKW. } \\
\text { suaminya. }\end{array}$ & $\begin{array}{l}\text { Percakapan yang sedang terlibat } \\
\text { antara Yati dan suaminya, } \\
\text { divisualisasikan dengan dialog } \\
\text { yenurut suami Yati, apabila dia } \\
\text { tidak bekerja maka tidak ada yang } \\
\text { mencari nafkah untuk keluarga. } \\
\text { Yati tidak boleh melawan karena } \\
\text { menurut suaminya, dialah kepala } \\
\text { keluarga yang berhak memutuskan } \\
\text { apapun. }\end{array}$ & $\begin{array}{l}\text { memperlihatkan ungapan- } \\
\text { ungkapan suami dari Yati yang } \\
\text { bertujuan untuk memaksa agar } \\
\text { Yati kembali bekerja sebagai } \\
\text { TKW untuk menafkahi rumah } \\
\text { tangga. Dalam scene ini, bahasa } \\
\text { berperan secara penuh sebagai } \\
\text { salah satumodus wacana. }\end{array}$ \\
\hline
\end{tabular}




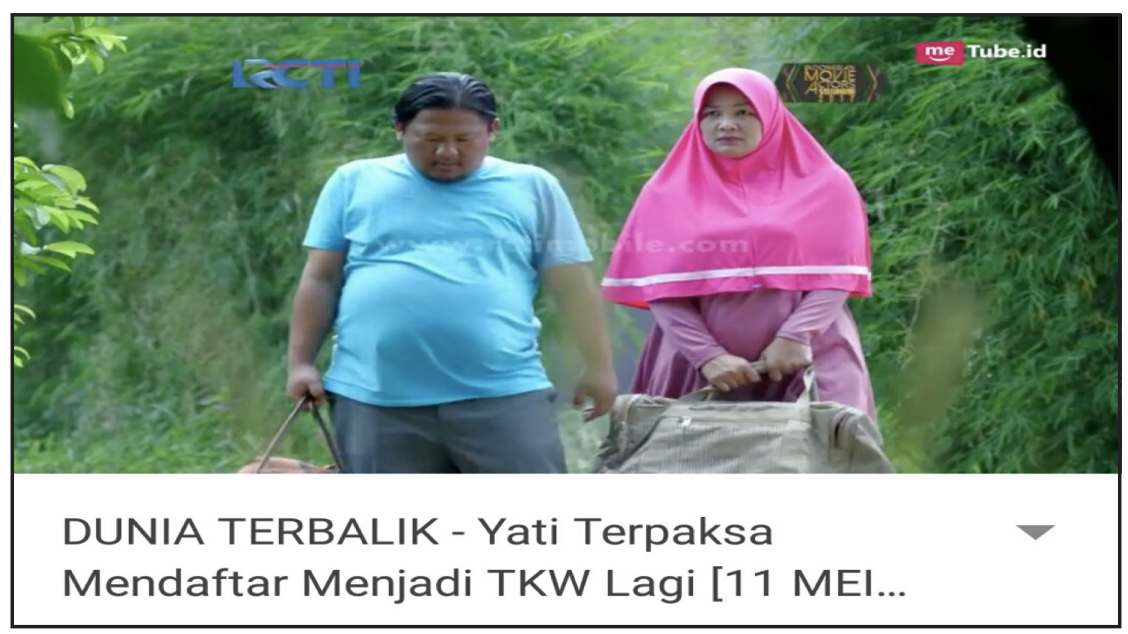

GAMBAR 5. Scene sinetron "Dunia Terbalik” 11 Mei 2017

Situasi ini juga menunjukkan fenomena suami yang sudah terlanjur mengandalkan istri dalam mencari nafkah sementara ia tidak bersifat melengkapi (komplementer) untuk menjalankan fungsinya dalam rumah tangga. Wacana ini menegaskan sebuah konsep seorang laki-laki/ suami yang tidak sepenuhnya menjalankan fungsinya yang berada dalam ranah domestik atau hanya menuntut pemenuhan haknya namun mengesampingkan peran dan kewajibannya sebagai laki-laki/ suami yang berperan dalam ranah domestik. Hal ini menimbulkan konflik.

Hal ini selaras dengan apa yang disampaikan Mawardi pada wawancara sebagai berikut:

Idealnya sih kalau menurut saya untuk laki-laki dan perempuan memiliki hakyang sama untuk berkegiatan di publik atau di luar rumah sepanjang antara yang satu kemudian tidak mengabaikan fungsinya masing-masing. Dan kemudian sebetulnya tentang tuntutan kewajiban. Misalnya yang sering dilupakan kan misalnya banyak dikatakan bahwa suami adalah pemimpin atau kepela rumah tangga yang berhak melakukan apapun sementara dia juga melupakan kewajibannya dan mengatasnamakan dalil-dalil dalam agama yang pada akhirnya diartikan sebagai superioritas yang mutlak yang masuk ke dalam berbagai ranah yang lebih luas bahkan sampai ke wilayah pemerintahan, politik, dan sebagainya.
Kalau dalam sinetron itu menurut saya sah-sah saja hanya saja kebanyakan saat ini yang terbentuk dalam masyarakat kan laki-laki merasa lebih unggul dan hanya meminta haknya sementara melupakan kewajibannya. Nah, kalau begitu kan jadi aneh. Laki-laki yang berada di wilayah domestik dan perempuan yang berada di wilayah publik menjadi bentuk ketidakadilan apabila ada pemahaman bahwa memang hal itulah yang harus dilakukan. Apabila sudah timbul asumsi seperti itu kan akan menjadi ketidakadilan.

Dari analisis-analisis melalui scenescene/adegan-adegan pada GAMBAR 4 dan GAMBAR 5, dapat disimpulkan bahwa laki-laki dan perempuan memiliki hak yang sama untuk berkegiatan di publik atau diluar rumah sepanjang antara yang satu kemudian tidak mengabaikan fungsinya masing-masing. Yang menjadi masalah apabila laki-laki merasa lebih unggul dan hanya meminta haknya sementara melupakan kewajibannya atau dengan kata lain pada akhirnya diartikan sebagai sebuah superioritas yang mutlak yang dimiliki oleh laki-laki.

\section{SIMPULAN}

Berdasarkan analisis dari penelitian yang telah peneliti lakukan dengan judul "Pertukaran Peran Laki-laki dan Perempuan dalam Rumah Tangga (Studi Analisis Wacana Halliday Mengenai Peran Domestik Laki-laki dan Peran 
Publik Perempuan dalam sinetron "Dunia Terbalik")", khususnya melalui adegan-adegan/secene-scene pada sinetron "Dunia Terbalik", secara tidak langsung mewujudkan suatu suasana yang dinamakan persamaan hak. Dalam tayangannya, memang tidak diperlihatkan suatu diskriminasi secara terang-terangan, namun diskriminasi yang lebih halus belumlah sepenuhnya hilang. Misalnya, pandangan bahwa semua wanita di Desa Ciraos harus menjadi TKW. Hal ini secara tidak langsung menunjukkan bahwa wanita tidak memiliki kebebasan konstruksi sosial. Wanita dapat memilih hendak menjadi apa tanpa tekanan dari adat kebiasaan.

Sutradara sinetron ini bisa menghindari bahwa para wanita di Desa Ciraos disediakan pilihan yang hanya akan menambah penindasan mereka. Namun, poin utamanya tetap tidak berubah, kebijakan sosial dapat digunakan merekonstruksi peran gender ketika peran tersebut dinilai tidak adil. Contoh saja bahwa dilema memilih antara keluarga dengan pekerjaan yang jauh di sana. Terkadang status pernikahan malah mengekalkan peran sosial wanita sebagai makhluk yang patuh, seperti yang sudah dilanggengkan oleh budaya patriarkhi yang selama ini notabene "dianut" oleh masyarakat Indonesia selama ini. Pelanggengan konsep/wacana seperti ini tidak lepas karena adanya penegasan melalui ketentuan pada Undang-Undang Perkawinan Nomor 1 Tahun 1974, Pasal 31 Ayat 3, yang menyatakan bahwa suami adalah kepala keluarga dan istri adalah ibu rumah tangga.

Perempuan yang berada di ranah domestik maupun publik akan tetap mengenakan atribut femininnya. Sekalipun mereka berada di sektor publik, mereka ditempatkan pada bidang yang lekat dengan pekerjaan perempuan, seperti yang biasa dilakukan pada ranah domestik. Hal inipun berlaku untuk sebaliknya.

\section{DAFTAR PUSTAKA}

Butt, D., Fahey, R., Spinks, S., \& Yallop, C. (1995). Using Functional Grammar: An Explorers Guide. Sydney: Macquary University.

Esplen, E. \& Jolly, S. (2006). Gender and Sex: a Sample of Definitions. Bridge (Genderand Development). University of Sussex, Brighton.

Halliday, M. A. K. dan Hasan, R. (1994). Bahasa, Konteks, dan Teks, Aspekaspek Bahasan Dalam Pandangan Semiotika Sosial. Yogyakarta: Gadjahmada University Press.

Hamad, I. (2007). Lebih Dekat Dengan Analisis Wacana. Jurnal Mediator. Vol. 8 No. 2, diakses pada Jumat, 11 Mei 2018 pukul 21.45 WIB.

Sobur, A. (2002). Analisis Wacana Teks Media, Suatu Pengantar untuk Analisis Wacana, Analisis Semiotik, dan Analisis Framing. Bandung: PT Remaja Rosda Karya.

Wiyatmi. (2008). Representasi Peran Dan Relasi Gender Dalam Novel Cantik Itu Luka Karya Eka Kurniawan Dan Nayla Karya Djenar Maesa Ayu. Laporan Penelitian, Universitas Negeri Yogyakarta.

Wibowo, E. D. (2011). Peran Ganda Perempuan dan Kesetaraan Gender. Jurnal Muwazah. Vol. 3, No. 1, hal. 356-373), download.portalgaruda. org/article.php?...PERAN\%20 GANDA\%20PEREMPUAN\%20. Diakses pada Senin, 6 November 2017 pukul 15.05. 